\title{
Mengukur Kelayakan Ekonomi Proyek Paperless Office dengan Metode Cost \& Benefits Analysis (Studi Kasus: Industri Garment)
}

\author{
Nancy Oktyajati*1 ${ }^{1}$ Sri Mayasari ${ }^{2}$, Hardik Widananto ${ }^{3}$ \\ ${ }^{1,2,3}$ Program Studi Teknik Industri, Universitas Islam Batik Surakarta \\ Jl. Agus Salim No.10, Sondakan, Laweyan, Surakarta, Jawa Tengah, 57147 \\ e-mail: ${ }^{* 1}$ oktyajati.nancy@gmail.com, ${ }^{2}$ mayyassari@gmail.com, \\ 3hardikwidananto@gmail.com
}

\begin{abstract}
Abstrak
Artikel ini membahas tentang studi kelayakan ekonomi dari proyek pengadaan perangkat komputer dan tablet pada perusahaan sebagai salah satu bagian usaha dalam paperless office. Tujuan dari penelitian ini adalah menganalisis kelayakan investasi untuk meningkatkan produktivitas, penghematan biaya, efisiensi tempat dan mengurangi dampak lingkungan. Perangkat komputer dan tablet digunakan untuk mengurangi biaya penggadaan dokumen yang biasanya dilakukan proses photocopy dan didistribusikan ke departemen lain. Pengukuran kelayakan investasi menggunakan Cost and Benefit Ratio Analysis. Perangkat ekonomi yang digunakan dalam studi kelayakan investasi ini antara lain Payback Period, Net Present Value (NPV), Return on Investment (ROI) dan Internal Rate of Return (IRR). Hasil analisis ekonomi dengan menggunaka metode cost benefit ratio untuk proyek paperless office adalah bahwa proyek layak diterima.
\end{abstract}

Kata kunci: cost \& benefit ratio, internal rate of return, net present value, paperless office, payback period, return on investment

\begin{abstract}
This paper discusses the economic feasibility study of the project of procuring computer and tablet devices to companies as one part of the business in the paperless office. The purpose of this study is to analyze the feasibility of investment to increase productivity, reduce costs, improve site efficiency and reduce environmental impacts. Computer and tablet devices are used to reduce the cost of procuring documents which are usually carried out by the photocopy process and distributed to other departments. Measurement of investment feasibility using Cost and Benefit Ratio Analysis. The economic tools used in this investment feasibility study include Payback Period, Net Present Value (NPV), Return on Investment (ROI) dan Internal Rate of Return (IRR). The results of economic analysis using the cost benefit ratio method for the paperless office project are that the project deserves to be accepted.
\end{abstract}

Keywords: cost \& benefit ratio, internal rate of return, net present value, paperless office, payback period, return on investment

\section{PENDAHULUAN}

Perkembangan teknologi informasi dan komunikasi memberikan berbagai kemudahan bagi manusia dalam menjalankan tugas dan pekerjaan. Berbagai kemudahan dapat dirasakan baik itu organisasi profit oriented dan non profit oriented. Peluang dikembangkannya teknologi informasi secara online dan dapat meninggalkan 
print out dan photo copy menggunakan kertas untuk surat menyurat dan dokumen dalam sebuah perusahaan dengna penerapan Paperless Office System. Perusahan perlu mempertimbangkan aspek ekonomis sebelum melakukan investasi teknologi (Hendarti, Nugroho and Legiastuti, 2011). Bagi perusahaan yang bersifat profit oriented bukan sesuatu yang sulit untuk beralih ke dalam teknologi informasi dalam setiap kegiatan produksi. Hal ini dikarenakan tingginya tingkat persaingan sehingga setiap perusahaan berupaya untuk melakukan perbaikan yang berkesinambungan (continous improvement). Salah satu cara kerja yang lebih efektif dan efisien adalah dengan paperless office (Orantes-Jimenez, Zavala-Galindo and Vazquez-Alvarez, 2015). Latarbelakang perlunya paperless office adalah mengurangi kerusakan lingkungan, kelebihan lainnya adalah biaya operasional yang lebih efektif serta mengurangi waktu transfer dokumen serta memudahkan dalam penyimpanan (Plimmer, 2007).

Beban biaya operasional yang ditanggung oleh perusahaan garment salah satunya adalah konsumsi kertas fotocopy Detail Order (DO) yang didistribusikan ke semua departemen produksi. Detail order merupakan alat yang vital bagi industri garment karena keseluruhan informasi order dari buyer tertcantum dalam Detail Order. Saat ini detail order didistribusikan ke departemen produksi dalam bentuk hardcopy. Sekitar $42.5 \%$ konsumsi kertas adalah digunakan untuk duplikasi detail order. Detail order digunakan untuk setiap style order yang akan diproduksi dilantai produksi. Ada 10 departemen produksi yang menggunakan detail order sebagai acuan kerja. Detail order bukan hanya digunakan oleh karyawan yang duduk di depan meja namun juga digunakan oleh karyawan dilantai produksi, serta digunakan di ruang meeting untuk review order sehingga detail order bersifat dokumen dengan mobilitas tinggi. Dengan adanya paperless office system ini perlu adanya alternative pengganti hard copy detail order dengan suatu perangkat computer dengan sifat mobile dan dapat diakses oleh banyak pihak dilantai produksi. Dengan pertimbangan aspek inilah perlu diciptakan central system dan mobile untuk mengakses detail order dalam bentuk data elektronik.

Kemajuan teknologi informasi dengan adanya internet dan sistem jaringan komputer memberikan kemudahan bagi perusahaan dalam penerapan paperless system. Dengan adanya teknologi tablet yang portable memberikan fleksibilitas bagi pengguna sebagaimana media kertas digunakan. Dengan adanya perubahan sistem dalam bekerja tentunya perlu adanya investasi sarana pendukung seperti pengadaan tablet serta perangkat komputer sebagai media pengganti kertas. Sebelum memutuskan pengadaan dengan investasi perlu dilakukan analisis kelayakan investasi yang akan memberikan pertimbangan penilaian yang akurat atas tingkat kelayakan secara ekonomis dalam pengembangan suatu sistem. Cara untuk mempermudah perhitungan bisnis dalam upaya mengetahui kelayakan sebuah bisnis maka perlu dilakukan analisis kelayakan investasi (Kapoyos, Robot and Sugiarso, 2014)

Metode kelayakan ekonomis yang digunakan adalah metode 'Cost \& Benefits Analysis' dimana dalam penilaian tersebut dilakukan identifikasi dan konversikan komponen-komponen penilaian yaitu biaya-biaya dan manfaat-manfaat yang dihasilkan oleh proyek sistem informasi tersebut ke dalam nilai ekonomis atau moneter. Kemudian dilakukan analisis kelayakan ekonomis dengan menggunakan alat-alat analisis finansial seperti Payback Period, Net Present Value, Return On Investment dan Internal Rate of Return (Hidayati and Warnana, 2017; Khumairoh et al., 2013; Irmayani, Yusuf and Muhammad, 2014). Dari hasil analisis tersebut dapat menjadi pertimbangan apakah proyek system informasi manajemen tersebut dapat diterima atau tidak. 
Benefit Cost Ratio didefinisikan sebagai rasio dari equivalent worth dari manfaat dengan equivalent worth dari cost/biaya. Pengukuran equivalent worth dapat diaplikasikan dalam present worth, annual worth, atau future worth, namun umumnya menggunakan Present worth atau Annual worth (Sullivan, Wicks and Koelling, 2014). Benefit Cost Ratio diandalkan sebagai metode analisis fundamental untuk proyek sektor publik. Benefit Cost Ratio didefinisikan sebagai rasio dari equivalent worth dari manfaat dengan equivalent worth dari biaya. Pengukuran equivalent worth dapat diaplikasikan dalam present worth, annual worth, atau future worth, namun umumnya menggunakan Present worth atau Annual worth (Sullivan, Wicks and Koelling, 2014). Cost and benefit ratio Analysis didasarkan pada dua komponen penilaian, yaitu komponen biaya dan komponen manfaat (Blank and Tarquin, 2012). Menurut Frederick H. Wu dalam bukunya Accounting Information Systems, Theory and Practice, komponen biaya yang berhubungan dengan pengembangan sebuah sistem informasi dapat diklasifikasikan dalam empat kategori, yaitu biaya pengadaan, biaya persiapan operasional, biaya proyek, biaya operasional. Sedangkan komponen manfaat atau -- dalam hal ini dapat disebut pula sebagai -- efektivitas yang di dapat dari sebuah sistem informasi dapat diidentifikasikan sebagai menafaat atau efektifitas dari pengurangan biaya, pengurangan kesalahan, peningkatan kecepatan aktivitas, peningkatan perencanaan dan pengendalian manajemen.

\section{METODE PENELITIAN}

Penelitian ini dilakukan pada industri germent dengan melakukan interview, studi literatur serta pengambilan data. Tahapan yang dilakukan dalam penelitian ini adalah mengumpulkan data rincian biaya yang dikeluarkan dalam investasi yang terdiri atas: procurement cost, start up cost, project related cost dan ongoing cost. Date tersebut dikumpulkan dari wawancara dengan pihak IT dan survei harga dari vendor yang memasok perangkat komputer. Tahap selanjutnya adalah mengumpulkan data rincian manfaat. Data ini diperoleh dari wawancara dengan departemen produksi dan departemen penunjang produksi (quality control, desain, engineer) terkait penghematan biaya dengan adanya investasi. Rincian biaya manfaat dibagi menjadi biaya tangible dan intangible cost. Tangibel cost merupakan manfaat yang secara langsung terlihat dengan adanya investasi ini. Manfaat tangible terdiri atas penghematan jumlah konsumsi kertas, serta penghematan waktu karena peningkatan kecepatan dalam pendistribusian data. Intangibel cost merupakan biaya yang secara tidak langsung terlihat yaitu manfaat peningkatan skill karyawan level operator dalam menggunakan teknologi informasi.

Setelah dilakukan perhitungan biaya manfaat dan biaya investasi, maka dilakukan perhitungan analisis investasi. Adapun metode-metode yang digunakan dalam cost \& benefits analysis diantaranya adalah payback period method, return on investment method, net present value method, dan internal rate of return method. Payback Period Method merupakan penilaian proyek investasi berdasar pada lamanya investasi tersebut dapat tertutup dengan aliran-aliran kas masuk, dan faktor bunga tidak dimasukan dalam perhitungan ini. Return On Investment (ROI) yang digunakan untuk mengukur prosentase manfaat yang dihasilkan oleh suatu proyek dibandingkan dengan biaya yang dikeluarkannya. Apabila suatu proyek investasi mempunyai ROI lebih besar dari 0 maka proyek tersebut dapat diterima.

Metode Net present value merupakan metode yang memperhatikan nilai waktu 
dari uang (Winarno, 2016). Metode ini menggunakan suku bunga diskonto yang akan mempengaruhi cash inflow atau arus dari uang. Bila nilai net present value $>0$, berarti investasi menguntungkan dan dapat diterima. Sama seperti NPV metode tingkat pengembalian internal atau IRR juga merupakan metode yang memperhatikan nilai waktu dari uang. Pada metode NPV tingkat bunga yang diinginkan telah ditetapkan sebelumnya, sedangkan pada metode IRR, kita justru akan menghitung tingkat bunga tersebut. Tingkat bunga yang akan dihitung ini merupakan tingkat bunga yang akan menjadikan jumlah nilai sekarang dari tiap-tiap cash inflow yang didiskontokan dengan tingkat bunga tersebut sama besarnya dengan nilai sekarang dari initial cash outflow atau nilai proyek. Dengan kata lain tingkat bunga ini adalah merupakan tingkat bunga persis investasi bernilai impas, yaitu tidak menguntungkan dan juga tidak merugikan. Dengan mengetahui tingkat bunga impas ini, maka dapat dibandingkan dengan tingkat bunga pengembalian atau rate of return yang diinginkan, jika lebih besar berarti investasi menguntungkan dan bila sebaliknya investasi tidak menguntungkan. Misalnya IRR yang dihasilkan oleh sebuah proyek adalah $25 \%$ yang berarti proyek ini akan menghasilkan keuntungan dengan tingkat bunga $25 \%$. Bila rate of return yang diinginkan adalah $20 \%$, maka proyek dapat diterima kelayakannya.

\section{HASIL DAN PEMBAHASAN}

\subsection{Biaya dan Manfaat}

Dalam studi kasus analisis benefit cost ratio ini dilakukan analisis terhadap perbandingan manfaat dan biaya atas investasi display monitor serta tablet sebagai pengganti dokumen detail order. Detail nilai biaya dan manfaat dari proyek pengadaan display monitor dan tablet ditampilkan pada Tabel 15 .

Tabel 15. Rincian biaya dan manfaat pengadaan monitor dan tablet (dalam Rp 000)

\begin{tabular}{|c|c|c|c|c|c|c|}
\hline & \multicolumn{6}{|c|}{ Tahun ke- } \\
\hline & 0 & 1 & 2 & 3 & 4 & 5 \\
\hline \multicolumn{7}{|l|}{$\begin{array}{l}\text { Rincian Biaya } \\
\text { 1. Procurement cost }\end{array}$} \\
\hline Monitor 43 inch & 35.000 & & & & & \\
\hline $\mathrm{CPU}+\mathrm{OS}^{*}$ & 59.500 & & & & & \\
\hline Tablet PC 10 inch & 45.650 & & & & & \\
\hline Bracket Monitor & 1.400 & & & & & \\
\hline Bracket CPU & 1.400 & & & & & \\
\hline Keyboard + Mouse & 2.002 & & & & & \\
\hline Rack Tab & 50 & & & & & \\
\hline Gembok + Kuncinya & 37 & & & & & \\
\hline Kabel HDMI & 245 & & & & & \\
\hline \multicolumn{7}{|l|}{ 2. Start Up cost } \\
\hline $\begin{array}{l}\text { Biaya instalasi } \\
\text { networking }\end{array}$ & 1.000 & & & & & \\
\hline Biaya reorganisasi & 331,2 & & & & & \\
\hline \multicolumn{7}{|l|}{$\begin{array}{l}\text { 3. Project Related } \\
\text { Cost }\end{array}$} \\
\hline Biaya survey & 441,6 & & & & & \\
\hline
\end{tabular}




\begin{tabular}{|c|c|c|c|c|c|c|}
\hline & \multicolumn{6}{|c|}{ Tahun ke- } \\
\hline & $\mathbf{0}$ & 1 & 2 & 3 & 4 & 5 \\
\hline Biaya koordinasi & 828 & & & & & \\
\hline Biaya training & 2.944 & & & & & \\
\hline \multicolumn{7}{|l|}{ 4. Ongoing Cost } \\
\hline Biaya maintenance & & 2.520 & 2.520 & 2.520 & 2.520 & 2.520 \\
\hline Biaya depresiasi (5\%) & & $7.264,2$ & $7.264,2$ & $7.264,2$ & $7.264,2$ & $7.264,2$ \\
\hline Total Cost & $150.828,8$ & $9.784,2$ & $9.784,2$ & $9.784,2$ & $9.784,2$ & $9.784,2$ \\
\hline \multicolumn{7}{|l|}{$\begin{array}{l}\text { Rincian benefit } \\
\text { 1. Tangible benefits }\end{array}$} \\
\hline $\begin{array}{l}\text { Efisiensi biaya } \\
\text { operasional }\end{array}$ & & 57.600 & 57.600 & 57.600 & 57.600 & 57.600 \\
\hline $\begin{array}{l}\text { Efisiensi biaya } \\
\text { distribusi\&komunikasi }\end{array}$ & & 2.760 & 2.760 & 2.760 & 2.760 & 2.760 \\
\hline \multicolumn{7}{|l|}{ 2. Intangible benefits } \\
\hline $\begin{array}{l}\text { Peningkatan } \\
\text { kemampuan SDM (40 } \\
\text { karyawan) }\end{array}$ & & 12.000 & 12.000 & 12.000 & 12.000 & 12.000 \\
\hline Total benefit & & 72.360 & 72.360 & 72.360 & 72.360 & 72.360 \\
\hline $\begin{array}{l}\text { Selisih total benefit } \\
\text { dengan cost }\end{array}$ & $-150.828,8$ & $62.575,8$ & $62.575,8$ & $62.575,8$ & $62.575,8$ & $62.575,8$ \\
\hline
\end{tabular}

\subsection{Metode Payback Period}

\begin{tabular}{ll} 
Investasi Awal & Rp150,828,800.00 \\
Cash inflow tahun 1 & Rp72,360,000.00 \\
Cash inflow tahun 2 & Rp72,360,000.00 \\
Cash inflow tahun 3 & Rp72,360,000.00 \\
Cash inflow tahun 4 & Rp72,360,000.00 \\
Cash inflow tahun 5 & Rp72,360,000.00 \\
Nilai investasi & $(\mathrm{Rp} 150,828,800.00)$ \\
Cash inflow tahun 1 & $\mathrm{Rp72,360,000.00}$ \\
\cline { 2 - 2 } Sisa investasi tahun 2 & $(\mathrm{Rp78,468,800.00)}$ \\
Cash inflow tahun 2 & $\mathrm{Rp72,360,000.00}$ \\
\cline { 2 - 2 } Sisa investasi tahun 3 & $(\mathrm{Rp} 6,108,800.00)$
\end{tabular}

Sisa investasi tahun 3 sebesar Rp. 6.108.800,- tertutup oleh sebagian cash inflow tahun 3 sebesar Rp. 72.360.000,-, yaitu Rp. 6.108.800,-/Rp. 72.360.000,- = 0.084 bagian. Payback period investasi ini adalah 2 tahun 1 bulan. Perusahaan menetapkan payback periode minimal 4 tahun sehingga proyek ini diterima.

\subsection{Metode Return on Investment (ROI)}

Berdasarkan data pada Tabel 15, diketahui bahwa total manfaat dari Proyek pengadaan display monitor dan tablet adalah :

Manfaat tahun ke $1 \quad$ Rp72,360,000.00

Manfaat tahun ke $2 \quad$ Rp72,360,000.00 
Manfaat tahun ke $3 \quad$ Rp72,360,000.00

Manfaat tahun ke $4 \quad$ Rp72,360,000.00

Manfaat tahun ke $5 \quad$ Rp72,360,000.00

Total Manfaat $\quad$ Rp361,800,000.00

Sedangkan total biaya yang dikeluarkan adalah:

Biaya tahun ke $0 \quad$ Rp150,828,800.00

Biaya tahun ke $1 \quad$ Rp9,784,200.00

Biaya tahun ke 2 Rp9,784,200.00

Biaya tahun ke $3 \quad$ Rp9,784,200.00

Biaya tahun ke $4 \quad$ Rp9,784,200.00

Biaya tahun ke $5 \quad$ Rp9,784,200.00

Total Biaya $\quad$ Rp199,749,800.00

ROI untuk proyek ini adalah sebesar :

$=(($ Rp. 361.800.000 - Rp. 199.749.800,-)/Rp. 199.749.800,- $) \times 100 \%=81.13 \%$. Proyek investasi mempunyai ROI lebih besar dari 0 maka proyek tersebut dapat diterima. Pada proyek ini nilai ROI nya adalah $81.13 \%$, ini berarti proyek ini dapat diterima, karena proyek ini akan memberikan keuntungan sebesar $81.13 \%$ dari biaya yang dikeluarkan.

\subsection{Metode Net Present Value (NPV)}

Berdasarkan data pada Tabel 15 kemudian dihitung besarnya nilai NPV dengan tingkat suku bunga diskonto yang diasumsikan adalah sebesar $10 \%$ per tahun.

$\begin{array}{ll}\text { Investasi Awal } & \text { Rp150,828,800.00 } \\ \text { Cash inflow tahun 1 } & \text { Rp72,360,000.00 } \\ \text { Cash inflow tahun 2 } & \text { Rp72,360,000.00 } \\ \text { Cash inflow tahun 3 } & \text { Rp72,360,000.00 } \\ \text { Cash inflow tahun 4 } & \text { Rp72,360,000.00 } \\ \text { Cash inflow tahun 5 } & \text { Rp72,360,000.00 } \\ \text { Tingkat Suku Bunga } & 10 \% \\ \text { Net Present Value } & \text { Rp123,472,530.63 }\end{array}$

Dari hasil perhitungan diketahui bahwa nilai NPV untuk investasi Proyek pengadaan display monitor dan tablet sebesar Rp. 123,472,530.63 ini berarti bahwa nilai NPV proyek tersebut $>0$ sehingga proyek tersebut dapat diterima.

\subsection{Metode Internal Rate of Return (IRR)}

Proyek pengadaan display monitor mensyaratkan IRR yang diharapkan dari proyek ini adalah 25\%, maka berdasarkan perhitungan menggunakan Microsoft Excel, dimana IRR sesungguhnya adalah 39\%, maka investasi untuk proyek ini dapat diterima kelayakannya. 


$\begin{array}{ll}\text { Investasi Awal } & - \text { Rp150,828,800.00 } \\ \text { Cash inflow tahun 1 } & \text { Rp72,360,000.00 } \\ \text { Cash inflow tahun 2 } & \text { Rp72,360,000.00 } \\ \text { Cash inflow tahun 3 } & \text { Rp72,360,000.00 } \\ \text { Cash inflow tahun 4 } & \text { Rp72,360,000.00 } \\ \text { Cash inflow tahun 5 } & \text { Rp72,360,000.00 } \\ \text { IRR disyaratkan } & 25 \% \\ \text { IRR sesungguhnya } & 39 \%\end{array}$

Analisis kelayakan investasi pengadaan CPU, monitor dan tablet sebagai salah satu investasi dalam penyelenggaraan paperless office dilakukan dengan menggunakan Analisis Benefit Cost Ratio. Perangkat ekonomi yang digunakan dalam studi kelayakan investasi ini yaitu Payback Period, Net Present Value (NPV), Return on Investment (ROI) dan Internal Rate of Return (IRR). Berdasarkan hasil dari empat instrument pengukuran kelayakan investasi tersebut secara keseluruhan dinyatakan layak. Dari sisi waktu pengembalian modal investasi, Payback periode dicapai 2 tahun 1 bulan lebih cepat dari target yang diisyaratkan perusahaan yaitu 4 tahun. Dari sisi keuntungan proyek ini akan memberikan keuntungan sebesar $81.13 \%$ dari biaya yang dikeluarkan.

\section{KESIMPULAN}

Hasil perhitungan yang didapat dari 'Cost \& Benefits Analysis' dengan menggunakan alat-alat analisis financial seperti Payback Period, NPV, ROI dan IRR memang dapat dimanfaatkan dalam membantu mengambil keputusan dalam menetapkan kelayakan secara ekonomis sebuah proyek paperless office dengan pengadaan display monitor di area produksi serta tablet. Berdasar analisis ekonomi benefit cost ratio diperoleh hasil secara analisis payback periode investasi akan kembali pada periose 2 tahun 1 bulan, Return Of Investment sebesar 81.13\%, Net present value sebesar Rp. 123,472,530.63, dan IRR sebesar 39\% dimana melebihi IRR yang disyaratkan. Dengan demikian dapat disimpulkan investasi ini layak secara analisis ekonomi.

\section{DAFTAR PUSTAKA}

Blank, L. and Tarquin, A, 2012, Engineering Economy Seven Teenth Edition, McGraw-Hill.

Hendarti, H., Nugroho, A. A. and Legiastuti, D, 2011, Analisis Investasi Sistem Informasi Dengan Menggunakan Metode Information Economics (Studi Kasus : PT . NASA), Seminar Nasional Aplikasi Teknologi Informasi 2011, Universitas Islam Indonesia, 17-18.

Hidayati, N. and Warnana, D. D, 2017, Analisis kelayakan finansial pengembangan kelas alam terbuka kebumian dan lingkungan berkonsep rekreasi dan inspirasi untuk anak di surabaya, Proceeding Sendi_U, 650-656. 
Irmayani, Yusuf, S. and Muhammad, N, 2014, Analisis kelayakan usaha budidaya rumput laut di desa mallasoro kecamatan bangkala kabupaten jeneponto, Jurnal Bisnis Perikanan (Journal of Fishery Business), vol. 1, no 1, 17-28.

Kapoyos, K. V., Robot, J. R. and Sugiarso, B. A, 2014, Identifikasi Manfaat dan Analisa Investasi Pada Perusahaan Software House (Studi Kasus: PT. XYZ), Jurnal Teknik Elektro dan Komputer, vol. 3, no. 1, 56-64.

Khumairoh, N. S. et al, 2013, Analisa investasi dengan Feasibility Study untuk meningkatkan Kecerdasan Finansial pada Budi Daya Ikan di Sidoarjo, DIE Jurnal Ilmu Ekonomi dan Manajemen, vol. 9, no. 2.

Orantes-Jimenez, S. D., Zavala-Galindo, A. and Vazquez-Alvarez, G., 2015, Paperless Office : a new proposal for organizations, Cybernetics and Informatics, vol. 13, no. $3,47-55$.

Plimmer, B., 2007, Making paperless work Making Paperless Work, In Proceedings of the 8th ACM SIGCHI New Zealand chapter's international conference on Computer-human interaction: design centered HCI, pp. 1-8.

Sullivan, W. G., Wicks, E. M. and Koelling, C. P., 2014, Engineering Economy Sixteenth Edition, Pearson Higher Ed.

Winarno, S. H., 2016, Analisis Penilaian Keputusan Investasi Menggunakan Metode Net Present Value, Moneter-Jurnal Akuntansi dan Keuangan. 